Original Research Paper

\title{
Back to Basics in the Importance of Market Orientation and Corporate Strategy to Bank Performances in Indonesia
}

\author{
Yunisyaaf Yunizal Arif \\ Department of Management, Perbanas Institute, Indonesia
}

Article history

Received: 31-07-2019

Revised: 11-10-2019

Accepted: 21-12-2019

Email: yunisyaaf.arief@perbanas.id

\begin{abstract}
This study was to see market orientation and corporate strategy to Bank performance, specifically product sales development, financial performance growth and market share growth in Indonesia. Unit analysis surveyed was a twelve (12) public listed commercial bank with the flexibility in the product offered and geographic coverage belongs to the group of BUKU III and BUKU IV under the Bank Indonesia classification. This study used the statistical reliable and valid Instrumentation. Given little samples, as they tell to a corporate strategy which is only formulated by the bank's headquarters, the results of studies were processed using partial least square's methods. Observations show that the dimensions of customer orientation dominate the preference on the bank's corporate strategy, followed by internal coordination and the least being a competitor orientation. The market orientation variables $( \pm 85.5 \%)$ influenced the strategy. Further observations also show that the approach $(84.4 \%)$ explained the bank performance $\%)$ whereas other factors $(26.6 \%)$ reflect other models.
\end{abstract}

Keywords: Market Orientation, Corporate Strategy, Banking Performance, Customer Orientation

\section{Introduction}

In accordance to the regulation issued by The Bank Indonesia in 2012, a circular letter No. $14 / 26 / \mathrm{PBI} / 2012$, the bank operates in Indonesia is clustered corresponds to their core capital and business activity to four (4) groups or BUKU:

1) Group I or "Bank Umum Atas Dasar Kegiatan Usaha (BUKU) I", are the bank that has a core capital of up to IDR 1.000.000.000.000 (One Trillion Rupiah)

2) Group II or "Bank Umum Atas Dasar Kegiatan Usaha (BUKU) II", are the bank has at Least IDR 1.000.000.000.000 (One Trillion Rupiah) up to less than IDR. 5.000.000.000.000 (Five Trillion Rupiah)

3) Group III or "Bank Umum Atas Dasar Kegiatan Usaha (BUKU) III", are the bank has at Least IDR 5.000.000.000.000 (Five Trillion Rupiah) up to IDR. 5.000.000.000.000 (Five Trillion Rupiah Up to less than IDR 30.000.000.000.000 (Thirty Trillion Rupiah)

4) Group IV or "Bank Umum atas Dasar Kegiatan Usaha (BUKU) IV" are the bank that has a core capital of more than IDR. 30.000.000.000.000,00 (Thirty Trillion Rupiah)

The banks that belong to the Group III and the Group IV relative to have more flexibility to perform various transactions and selling various products standardize to the Indonesian market. The banks are also able to have their presence in the Asia region (group III) or Worldwide (group IV).

Up to now, most of the bank performance operated in Indonesia were not stable and tended to fluctuate over the time. The third-party funding and loan activities were not comparable to market demand for loans. The reason for this may be due to the product offered are not yet reckoning the market demands. To wit, the bank market orientation is failed to respond some opportunities from the market. Such limitation in the product update that matches the customer demands locally or internationally, cause the banks always behind the market access.

Consider that phenomena. This study is aimed to see the followings:

1. The level of implementation on the dimension of market orientation 
2. The effect of market orientation dimension to the corporate strategy in explaining the bank performance, as one or partially

\section{Theoretic Framework}

\section{a. Market Orientation}

Market Orientation (MO) is one of the topics related to the company's strategy in the marketing activities of products and services. Even academics and business practitioners perceive that market orientation is central to marketing management and strategy (Narver and Slater, 1990). The level of company implementation towards market orientation describes the level of an employee commitment to creating customer satisfaction, the higher the level, the higher satisfaction level is achieved and could even reach their best value and give a positive impact to the company performance. Empirically, the relationship between $\mathrm{MO}$ and company performance is not only found in the company producing the products but also it exists in the service company. This phenomenon is not surprising, considering the service companies such as banking highlighted the service to its customers.

Similarly, Udoyi (2014) has studied the relationship between MO and Commercial Bank Performance in Kenya. His research on 43 commercial banks in Kenya, has proven that the market-oriented corporate strategy affects the bank's performance, so the concerned advises that banks should consider the needs of their customers rather than competitors.

Furthermore, different scholars have also shown a correlation between a. MO to profitability (Bhuian, 1997; Greenley, 1995), b. MO to a market share (Deshpande et al., 1993; Pelham and Wilson, 1996), c. MO to the success of new product sales (Appiah-Adu, 1997); d. MO to customer satisfaction (Gray et al., 1998).

One essential characteristic of a market based oriented companies is they have a complete understanding towards its customers. Such marketoriented companies often achieved higher profits compared to the less market-oriented companies (Day, 1994). MO is a multidimensional aspect, which may reflect a company decided to focus on competitors, customers or both. The market-oriented company could harmonize its internal environment with their external environment. (Heiens, 2000); the company has a comprehensive understanding towards the revealed or not revealed demands (Slater, 2001).

Marketing approach in commercial banking activities het along been known ever since the 1950s, especially in western countries. It is driven by the desire of bankers to create new markets and an effort to plan and to market new products and services to customers effectively and efficiently. Marketing for the bank is not only performing a product sale and services but also means how we create a bank 's reputation in the eyes of its customers.

Similar research conducted by Abuzid and Abbas (2017) on Saudi Arabia Banks, related to the effect of a market orientation strategy to business performance with the employee and the customer satisfaction as mediating variables indicated that the market orientation strategy has a significant effect on bank performance

Today as every commercial bank competes to provide the best products and services to its customers, then the bank must be able to provide better features when compared to its competitors. Better features on products and services mean more costs, not only to the bank but also to the customers. Therefore, to overcome such expenses while maintaining the lowest cost possible, the banks need to increase more new customers or more transactions from the existing customers.

The higher customer numbers often with a rapid change in customer perceptions towards the bank products and services, making the bank not easy to meet every customer's demands. The inability of banks to provide such products or services as requested by customers, prompting customers to have multiple accounts with various banks. The lack of products or services as offered by their bank, lead the customers to seek from different sources for example: from their second, third or fourth banks. Therefore, banks are faced with a difficult choice, to become a universal bank or a specialize bank offering a specific product? Given the shrinking market share that is coupled with decreasing spreads and margins.

Learning from Asikhia (2010), which says that the dimension of MO for banks may include: Customer orientation, competitor orientation and the uncertainty of customer needs and technological uncertainty, means the banks shall decide which dimension shall be adopted in their strategy.

From studying of Mahmoud (2011), to the banking in Ghana, it is found that customer orientation dimension dominates the banking strategy, whereas the internal orientation dimension is still employed.

In practice, most of the Indonesian banking company is still relies on its specific product with non-flexible tariff and procedure. To wit, the offering of new products and services with the flexible procedure following the specific customer demands may not be available. Such things will drive a few regular customers looking for an alternative bank that provides both ease of the procedure and tariff flexibility. The competitors who understand such things may compete for the same market.

According to Narver and Stanley (2009), the competitor orientation means understanding the strengths and weaknesses of competitors. Whereas the customer orientation means understanding the needs of customers and potential customers. 


\section{b. Bank Performance}

The bank performance is a consolidation achievement of several existing business units in the bank. Maintaining high profitability and hence distribute a value dividend to the shareholders is one of the aims of every bank, especially to those of the public listing banks. The high achievement of a bank is one hint that the bank has been complying with the prudential principle.

The increase in the stock value together increasing of third-party funding, whether from saving, current accounts and deposits as well as from correspondent banks is one indicator that the bank succeeded to gain public confidence over the bank activities. Trust and loyalty to the bank is a factor that is helpful and would simplify the bank management to run a good business strategy.

Although there is a standard evaluation procedure for bank performances as a guide from authorities, every bank with their specialty shall be able to cope with the business dynamics and be able to tailor their evaluation system to align with their own conditions. One of the performance measure for banking ever developed is the CAMELS system. The CAMELS is an acronym for $\mathrm{C}=$ Capital Adequacy; A = Asset quality; $\mathrm{M}=$ Management; $\mathrm{E}=$ Earnings $; \mathrm{L}=\mathrm{S}=$ Liquidity and Sensitivity to Market Risk (Rose and Hudgins, 2010), is now widely used by banking regulators in various countries. Besides, the banks were also assessed based on the three (3) approaches, namely: Asset; Market and Revenue (Deev, 2011).

In this study the variables with their dimensions examined were:

- The growth of product sales; the growth of financial performance; and the growth of a market share

- The dimension of the product's sales consists of such indicators as the level of Third Party Funding (TPF) and The level of Credit Growth

- The Dimension of Financial Performance consists of such financial ratios as ROA; ROE and Profit

- The dimension of a Market Share composed of the percentage market share

\section{c. Corporate Strategy}

The definition of corporate strategy is a strategy of the company that requires the company's top managers decisions that address the satisfaction of the company's stakeholders. The managers at the corporate level decide what market and business to be conducted to generate long-term profit maximization and to improve the company's revenue shareholders. Therefore, to design a corporate strategy the top manager shall define the corporate vision and mission, a business strategy considering the market characteristics, strength and weaknesses with company's capabilities compared to their competitors. Furthermore, the company's strategy is differentiated into two different dimensions associated with growth (Zook and Rogers, 2001) and liquidity (Kim et al., 1998).

The corporate strategy also means a selection of the company's product portfolio, which directs the company whole. Before formulating the corporate strategy a comprehensive analysis and review of the company's internal and external environment, employing such strategic tools as SWOT analysis, BCG and others.

Dhar and Sundararajan (2009) have described a corporate strategy which focuses on a various growth strategy for the company in detail. Further efforts to improve the synergy between the units in banks through mergers and acquisitions is one representation of the strategy to grow horizontally and vertically (Pinter, 2011). Portfolio strategy undertaken in the manufacturing industry related to the product development as an attempt to do a profit maximization is also carried out in banking. For example, the portfolio strategy for the acquisition and the merger of the banking in Italy (Alessandrini et al., 2006).

Belongs to a Corporate strategy, a corporate parenting strategy is a strategy with the aim to build synergies through sharing resources, capabilities and development of the business unit or units in the company's existing products strategy is commonly used for companies that have a variety of business units or different product.

\section{d. Market Orientation and Bank Performance}

That market-oriented companies often have a better performance compared to the non-market-oriented companies reflects that such market-oriented companies are a determining factor for a company superior performance. The relationship between MO and bank performance has also been investigated by several scholars, for example: Friesen (2013; Zaman et al., 2012; Mahmoud, 2011).

\section{e. Corporate Strategy and Bank Performance}

Although the influence of corporate strategy on firm performance has been widely accepted, an understanding of the relationship between the two is still very minimal (Doise, 2008). This study will analyze the relationship between corporate strategy and its affect corporate performances. Similar studies over different industries have also investigated by Doise (2008), while Hofmann (2010) investigates the relationship between Corporate Strategy decisions (CS) and Supply Chain Management (SCM) to the company performance.

From the description as above, the theoretical background of this study is as shown in Fig. 1. 


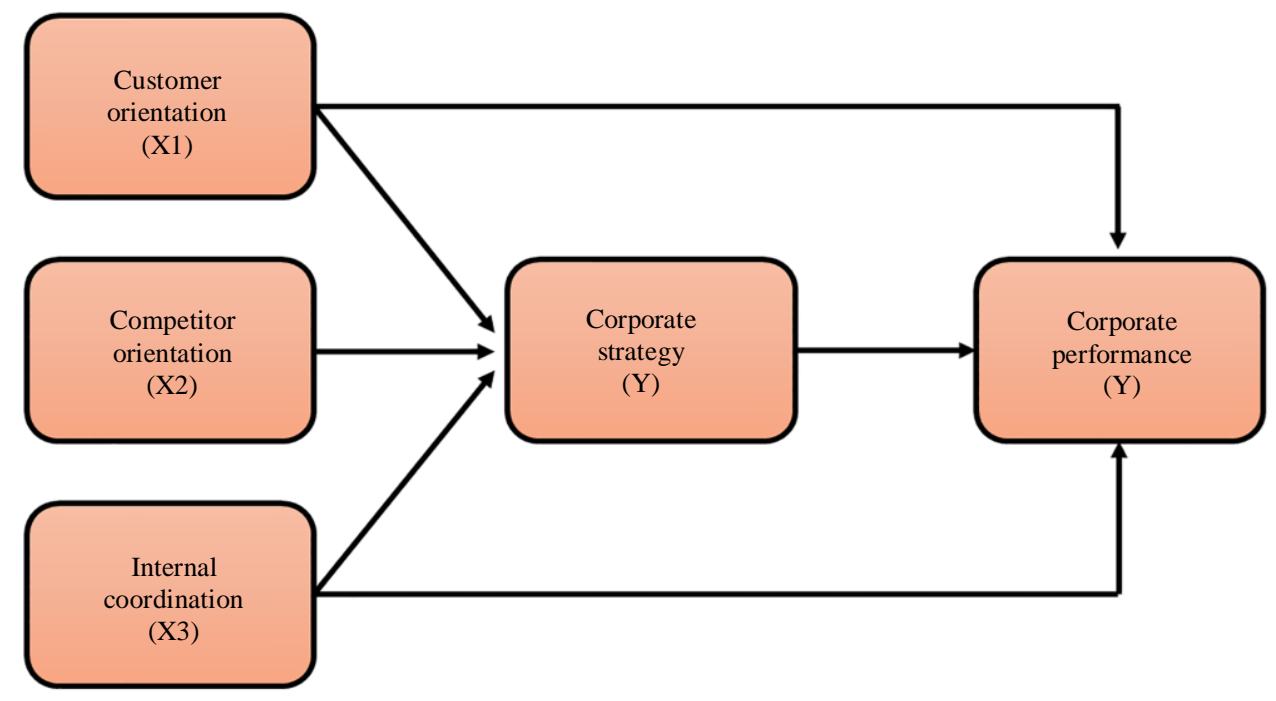

Fig. 1: The research paradigm

\section{Research Hypotheses}

In this paper, we analyzed three (3) hypotheses:

- The dimensions of market orientation adopted by banks in Indonesia are all equally important in explaining the commercial bank performances

- The market orientation as adopted by commercial banks in Indonesia influences the corporate strategy either one or partially and this event will reflect the bank performance

- The implementation of market orientation by Indonesian commercial banks will positively impact the corporate performance as mediated by a corporate strategy

\section{Methodology}

In this study, the sample under observation is the public listing bank belong to the BUKU III and BUKU IV groups, with the consideration that such banks more than have no limitation in the product scope variables and sites, in other words, a bank not constrained by central bank's product range or location. The bank is capable of operating in domestic and international markets. The number of banks observed was twelve (12) banks; the data collection is by a census method.

In this study, the top Management (i.e., Board of Director or Directors) that received the questionnaire will later distribute to the SubDivision in-charge.

Having consolidated the data as received from every unit, further clarification on a vague answer performed via in-depth interviews with the relevant unit.

\section{The Determination}

The Reliability and the validity of the Questionaire is measured via Cronbach's Alpha as in Table 1.

Convergent validity of all indicators towards each variable as in Table 5 (appendix), has shown that all indicators are valid to measure all latent variables.

\section{Finding and Discussion}

The results of primary data processing using SEMPLS (SmartPLS) as in Table 5. Loading Factor of all variables and Fig. 3. The Path Cofficient of Research Model (SmartPLS). Furthermore, the results of The Structural Testing Model (Inner Model) as in in Table 2 The results of Structural Model or Inner Model evaluation as in Table 2.

Data from Table 2 reflects that the model is, in fact, comparable with an empiric condition or model fit.

The effect of orientation dimension to the corporate strategy and to the bank performances as demonstrated in the Fig. 2.

From the diagram, the structural model that applied is as follows:

$$
\begin{aligned}
& Y=0,499 X_{1}+0,196 X_{2}+0,263 X_{3}+\zeta_{1} \\
& Z=-0,043 X_{1}+0,150 X_{2}+0,042 X_{3}+0,783 Y+\zeta_{2}
\end{aligned}
$$

Results of this study reflected that the customer orientation $(50 \%)$ dictates the corporate strategy followed by the Internal coordination (26\%) and the lowest $(19.6 \%)$ is the competitor orientation. The basic calculation of the consumer orientation, competitor 
orientation and internal co-ordination variables used in the analysis is the ordinal scale such as the attitude of an individual to an argument, in the form of strongly agree, agree, be normal, disagree, strongly disagree, each of which has a value of 5,4,3,2 and 1. Meanwhile hypothesis testing on each dimension as in Table 3.

As in the above table, the data demonstrated that the market orientation dimension is not equally necessary to explain the choice on the corporate strategy, the customer orientation being the dominant dimension for the bank under observation. The endogenous variable (corporate strategy) is together influenced by the market orientation $( \pm 85.5 \%)$, whereas $15.6 \%$ by other factors outside the model.

Furthermore, Table 4 represents a partial hypothesis testing on the market orientation dimension towards the bank performance.

The results as above have shown that the market orientation does not directly affect the bank performance. Alongside a corporate strategy that explains the majority
$(84.4 \%)$ of the model, furthermore for as much as $16.6 \%$ of the model is explained by other factors.

Table 1: The reliability and validity of measurement

\begin{tabular}{llll}
\hline Variables & & $\begin{array}{l}\text { Composite } \\
\text { reliability }\end{array}$ & $\begin{array}{l}\text { Cronbach's } \\
\text { alpha }\end{array}$ \\
\hline Customer orientation & $(\mathrm{X} 1)$ & 0.967 & 0.962 \\
Competitor orientation & $(\mathrm{X} 2)$ & 0.978 & 0.975 \\
Internal coordination & $(\mathrm{X} 3)$ & 0.976 & 0.970 \\
Corporate strategy & $(\mathrm{Y})$ & 0.967 & 0.961 \\
Bank performance & $(\mathrm{Z})$ & 0.911 & 0.876 \\
\hline
\end{tabular}

Source: Data analysis by Smart PLS (2017)

Table 2: The structural model testing (inner model)

\begin{tabular}{llll}
\hline Variable & & R-Square & $\begin{array}{l}\text { Communality } \\
\text { GOF* }\end{array}$ \\
\hline Customer Orientation & (X1) & & 0.746 \\
Competitor Orientation & (X2) & & 0.803 \\
Internal Coordination & (X3) & 0.869 & 0.806 \\
Corporate Strategy & (Y) & 0.855 & 0.733 \\
Bank Performance & (Z) & 0.844 & 0.675 \\
\hline
\end{tabular}

* GOF = Goodness of Fit

Table 3: The partial test of the marker orientation dimension

\begin{tabular}{lllllll}
\hline Structural model & $\gamma$ & Standard error & T-count & R-square $\left(\mathrm{R}^{2}\right)$ & F-count & Notes \\
\hline XI->Y & 0.499 & 0.098 & 5.083 & 0.855 & 15.690 & Not Significant \\
X2->Y & 0.196 & 0.138 & 1.419 & & Not Significant \\
X3->Y & 0.263 & 0.127 & 2.073 & & Not Significant \\
\hline
\end{tabular}

* Significant at $\alpha=0,05$

Table 4: The partial test of every variable to corporate performance

\begin{tabular}{|c|c|c|c|c|c|c|}
\hline Structural model & $\gamma$ & standard error & T-count & $\mathrm{R}$-square $\left(\mathrm{R}^{2}\right)$ & F-counrt & Notes \\
\hline$\overline{X 1->Z}$ & -0.043 & 0.074 & 0.580 & 0.844 & 14.447 & Not Significant \\
\hline X2-> Z & 0.150 & 0.253 & 0.593 & & & Not Significant \\
\hline X3-> Z & 0.042 & 0.200 & 0.208 & & & Not Significant \\
\hline Y-> Z & 0.783 & 0.062 & 12.281 & & & Significant \\
\hline
\end{tabular}

*Significant at $\alpha=0.05$

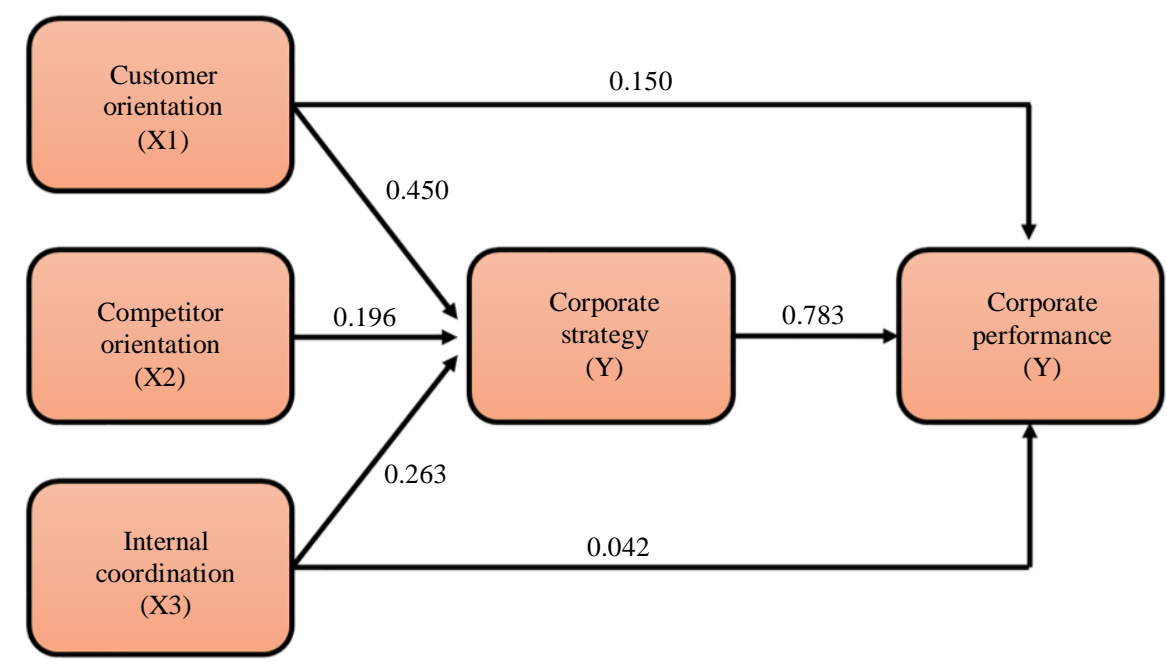

Fig. 2: Path diagram 


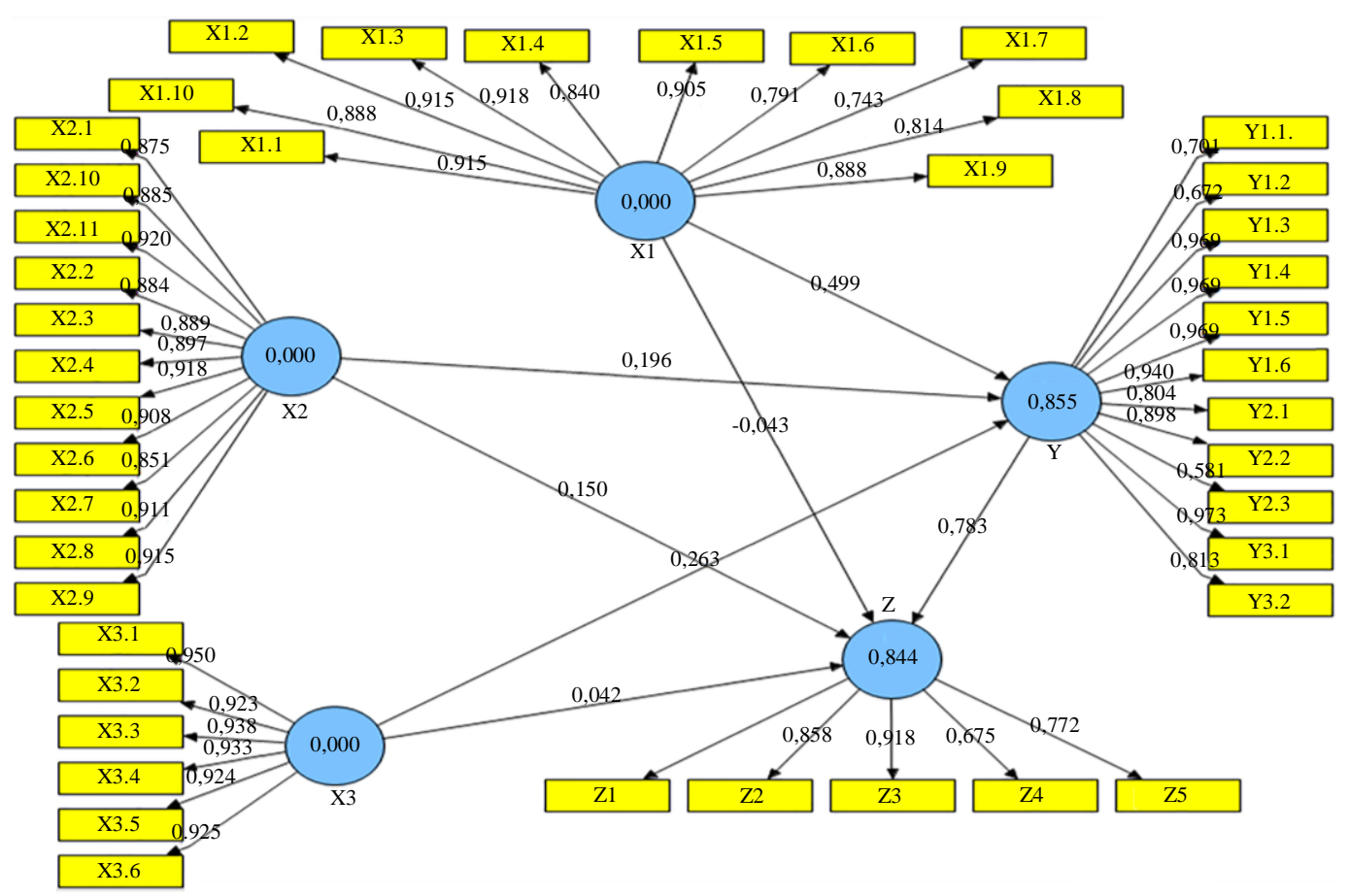

Fig. 3: The path coefficient of research model (SmartPLS)

\section{Conclusion and Future Recommendation}

This study found that customer orientation dominates the market orientation of the banks under observation. Whereas the competitor orientation is the least dimension to be concerned with most banks, this event may be related to the ability of the bank to gather information due to some limitation in supporting tools or may be due to budget constraints. Further investigation related to budget allocation or other variables that affect the bank performance may be required.

\section{Acknowledgement}

This work was made possible by Perbanas's great assistance, which gave the impetus to communicate with the banks that were the focus of the study.

\section{Ethics}

This research has been carried out with the advice of Prof. Dr. H. Sucherly, S.E., M.S., University of Padjadjaran, Bandung, to understand the quality of commercial banks in Indonesia

\section{References}

Abuzid, H.F.T. and M. Abbas, 2017. Banks performance and impact of market orientation strategy: Do employee satisfaction and customer loyalty augment this relationship. Int. Rev. Manage. Market., 7: 60-66.
Alessandrini, P., G. Calcagnini and A. Zazzaro, 2006. Asset restructuring strategies in bank acquisitions: Evidence from the italian banking industry. SSRN Electronic J.

Appiah-Adu, K., 1997. Market orientation and performance: Do the findings established in large firms hold in the small business sector. J. Euro. Market., 6: 1-26. DOI: 10.1300/J037v06n03_01

Asikhia, O., 2010. Customer orientation and firm performance among Nigerian small and medium scale businesses. Int. J. Market. Stud., 2: 197-212. DOI: 10.5539/ijms.v2n1p197

Bhuian, S.N., 1997. Exploring market orientation in banks: an empirical examination in Saudi Arabia. J. Service Market., 11: 317-328. DOI: $10.1108 / 08876049710176006$

Day, G.S., 1994. Continuous learning about markets. California Manage. Rev. DOI: $10.2307 / 41165764$

Deev, O., 2011. Methods of bank valuation: A critical overview. Department Finance, Faculty of Economics and Administration, Masaryk University.

Deshpande, R., J.U. Farley and J.F.E. Webster, 1993. Corporate culture, customer orientation and innovativeness in Japanese firms: A quadrad analysis. J. Market., 57: 23-37. DOI: $10.2307 / 1252055$

Dhar, V. and A. Sundararajan, 2009. Plugging into transformation. Financial Times, Managing in a Downturn Series. 
Doise, M.L., 2008. An integration of corporate culture and strategy, the interrelationships. Impact Firm Performance a Dissertation University Arkansas

Friesen, D.P., 2013. The relationship of market orientation, absorptive capacity, organizational learning and positional advantage to corporate performance in turbulent and non-turbulent environments. PhD Thesis, Wayne State University.

Gray, B., S. Matear, C. Boshoff and P. Matheson, 1998. Developing a better measure of market orientation. Eur. J. Market., 32: 884-903. DOI: $10.1108 / 03090569810232327$

Greenley, G.E., 1995. Market orientation and company performance: Empirical evidence from UK companies. British J. Manage., 6: 1-13. DOI: $10.1111 / \mathrm{j} .1467-8551.1995 . t b 00082 . x$

Heiens, R.A., 2000. Market orientation: Toward an integrated framework. Acad. Market. Sci. Rev., 1: 1-5.

Hofmann, E., 2010. Linking corporate strategy and supply chain management. Int. J. Phys. Distribut. Logist. Manage., 40: 256-276.

DOI: $10.1108 / 09600031011045299$

Kim, C.S., D.C. Mauer and A.E. Sherman, 1998. The determinants of corporate liquidity: Theory and evidence. J. Financial Quantitative Anal., 33: 335-359. DOI: $10.2307 / 2331099$

Mahmoud, M.A., 2011. Market orientation and business performance among SMEs in Ghana. Int. Bus. Res., 4: 241-251. DOI: 10.5539/ibr.v4n1p241

Narver, J.C. and F.S. Stanley, 2009. The effects of a market orientation on business profitability. J. Market.
Narver, J.C. and S.F. Slater, 1990. The effect of a market orientation on business profitability. J. Market., 54: 20-35. DOI: 10.1177/002224299005400403

Pelham, A.M. and D.T. Wilson, 1996. A longitudinal study of the impact of market structure, firm structure, strategy and market orientation culture on dimensions of small-firm performance. J. Acad. Market. Sci., 24: 27-43. DOI: 10.1007/BF02893935

Pinter, E., 2011. Merger and acquisition in the financial industry. Int. J. Social Sci. Humanity Stud., 3: 1309-8063.

Rose, P. and S. Hudgins, 2010. Bank Management and Financial Services. 8th Edn., McGraw-Hill/Irwin, ISBN-10: 0071269657, pp: 734.

Slater, S.F., 2001. Market orientation at the beginning of a new millennium. Manage. Service Quality, 11: 230-230. DOI: 10.1108/EUM0000000005609

The Bank Indonesia, A Circular Letter No.14/26/PBI/2012

Udoyi, C.O., 2014. Relationship between market orientation and performance of commercial banks in Kenya a research project report submitted in partial fulfillment of the requirements for the award of the degree of master of master of business administration. School of Business, University of Nairobi.

Zaman, K., J. Neelum, A. Asma and B. Samina, 2012. Impact of internal marketing on market orientation and business performance. Int. J. Bus. Social Sci., 3: 76-87.

Zook, C. and P. Rogers, 2001. In pursuit of growth. Eur. Bus.J., 13: 83-85.

\section{Appendix}

Table 5: Loading factor of all variables

\begin{tabular}{|c|c|c|c|}
\hline & $\lambda$ & Standard Error (STERR) & T Statistics (|O/STERR $\mid)$ \\
\hline XI.I <- XI & 0.915 & 0.022 & 42.199 \\
\hline XI.10 <- XI & 0.888 & 0.017 & 51.690 \\
\hline XI. $2<-$ XI & 0.915 & 0.022 & 42.199 \\
\hline $\mathrm{X} 1.3<-\mathrm{XI}$ & 0.918 & 0.021 & 44.084 \\
\hline $\mathrm{X} 1.4<-\mathrm{XI}$ & 0.840 & 0.037 & 22.895 \\
\hline $\mathrm{X} 1.5<-\mathrm{XI}$ & 0.905 & 0.020 & 45.781 \\
\hline $\mathrm{X} 1.6<-\mathrm{XI}$ & 0.791 & 0.046 & 17.116 \\
\hline XI. $7<-$ XI & 0.743 & 0.038 & 19.583 \\
\hline $\mathrm{X} 1.8<-\mathrm{XI}$ & 0.814 & 0.030 & 27.277 \\
\hline X1.9<- XI & 0.888 & 0.017 & 51.690 \\
\hline$X 2.1<-X 2$ & 0.875 & 0.020 & \\
\hline$X 2.10<-X 2$ & 0.885 & 0.016 & 55.702 \\
\hline $\mathrm{X} 2.11<-\mathrm{X} 2$ & 0.920 & 0.009 & 98.196 \\
\hline$X 2.2<-X 2$ & 0.884 & 0.022 & 40.278 \\
\hline $\mathrm{X} 2.3<-\mathrm{X} 2$ & 0.889 & 0.019 & 47.296 \\
\hline $\mathrm{X} 2.4<-\mathrm{X} 2$ & 0.897 & 0.018 & 48.766 \\
\hline$X 2.5<-X 2$ & 0.918 & 0.014 & 64.683 \\
\hline$X 2.6<-X 2$ & 0.908 & 0.210 & 43.842 \\
\hline$X 2.7<-X 2$ & 0.851 & 0.034 & 24.994 \\
\hline $\mathrm{X} 2.8<-\mathrm{X} 2$ & 0.911 & 0.014 & 67.329 \\
\hline$X 2.9<-X 2$ & 0.915 & 0.011 & 81.715 \\
\hline
\end{tabular}


Yunisyaaf Yunizal Arif / American Journal of Economics and Business Administration 2019, Volume 11: 78.85 DOI: 10.3844/ajebasp.2019.78.85

Table 5: Continue

\begin{tabular}{|c|c|c|c|}
\hline $\mathrm{X} 3.1<-\mathrm{X} 3$ & 0.950 & 0.012 & 77.8210 \\
\hline$X 3.2<-X 3$ & 0.923 & 0.012 & 80.0090 \\
\hline $\mathrm{X} 3.3<-\mathrm{X} 3$ & 0.938 & 0140 & 67.3060 \\
\hline$X 3.4<-X 3$ & 0.933 & 0.011 & 87.5610 \\
\hline$X 3.5<-X 3$ & 0.924 & 0.010 & 92.7480 \\
\hline$X 3.6<-X 3$ & 0925 & 0.016 & 56.2310 \\
\hline Y1.1. <- y & 0.721 & 0.051 & 14.2400 \\
\hline YI. $2<-$ Y & 0.673 & 0.062 & 10.8020 \\
\hline YI.3<-Y & 0.969 & 0.005 & 192.165 \\
\hline$Y 1.4<-Y$ & 0.969 & 0.005 & 192.165 \\
\hline$Y 1.5<-Y$ & 0.969 & 0.005 & 192.165 \\
\hline$Y 1.6<-Y$ & 0.940 & 0.010 & 92.9160 \\
\hline$Y 2.1<-Y$ & 0.804 & 0.016 & 51.0940 \\
\hline$Y 2.2<-Y$ & 0.898 & 0.012 & 76.7540 \\
\hline$Y 2.3<-Y$ & 0.581 & 0.115 & 5.05400 \\
\hline$Y 3.2<-Y$ & 0.813 & 0.035 & 23.1240 \\
\hline $\mathrm{ZI}<-\mathrm{Z}$ & 0.864 & 0.026 & 32.9460 \\
\hline $\mathrm{Z} 2<-\mathrm{Z}$ & 0.858 & 0.017 & 51.0410 \\
\hline$Z 3<-Z$ & 0.918 & 0.013 & 68.2590 \\
\hline $\mathrm{Z} 4<-\mathrm{Z}$ & 0.675 & 0.066 & 10.2050 \\
\hline$Z 5<-Z$ & 0.772 & 0.054 & 14.1660 \\
\hline
\end{tabular}

